\title{
Rationality and Irrationality in Military Organizations
}

\author{
Joseph Soeters
}

\section{Contents}

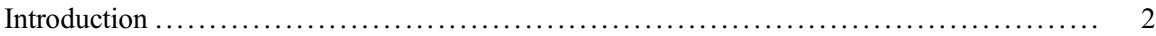

Striving for Rationality in the Build-Up of Military Organizations $\ldots \ldots \ldots \ldots \ldots \ldots \ldots \ldots \ldots, \quad 3$

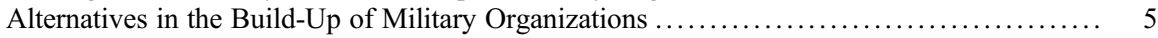

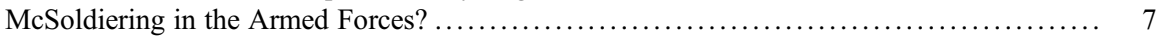

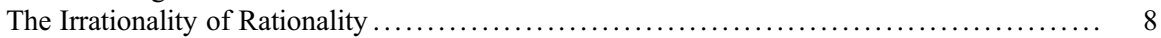

Limits to Rationality in Decision-Making ..................................... 9

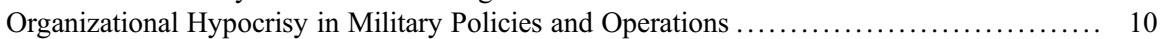

Collateral Damage, Functional and Substantive Rationality ......................... 13

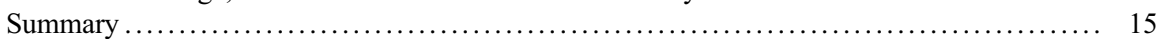

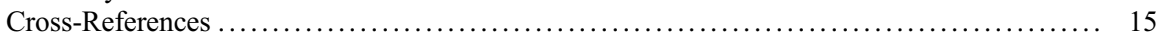

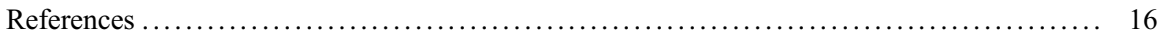

\section{Abstract}

This chapter delves into a variety of issues dealing with rationality, irrationality, and everything in between, as they occur in military organizations. Respectively, this contribution examines the rationality behind the structure of military organizations, including its room for improvement based on contemporary experiences and insights, such as modular organizing. Next, the chapter deals with the possible McSoldiering of the military and the risk that rationality may turn irrational. Subsequently, the limits of rationality in military decision-making will be examined, after which elements of organizational hypocrisy in military action will be assessed. At the end, the phenomenon of collateral damage as a consequence of military action and the way the military often deals with this phenomenon, are considered. The aim of this chapter is to spawn insights and understanding of the many dilemmas that military organizations face continuously, on and off the area of operations, consciously and subconsciously.

\footnotetext{
J. Soeters $(\square)$

Department of Organization Studies, School of Social and Behavioural Studies, Tilburg University, Tilburg, The Netherlands
} 


\section{Keywords}

Rationality $\cdot$ Functional/substantive rationality $\cdot$ Irrationality $\cdot$ Organizational structure $\cdot$ McSoldiers · Strategic decision making · Organizational hypocrisy · Collaterale damage

\section{Introduction}

As long as the military organization has existed, there has been discussions about the character of warfare and military action. Some say the military is the specimen of rationality in all its facets of planning, the disciplined structuring of activities, and the use of technologies, whereas others tend to stress the emotional, unrestrained, "foggy," and even short-sided side of military operations. This debate is unlikely to be solved easily, and this is not what this chapter aims to do.

This chapter has the humble intention to delve a bit deeper into matters of rationality, or the lack thereof, in the military. The emphasis will be on aspects that have been uncovered in the field of sociology and management and organization studies (e.g., Soeters 2018, 2020; Soeters et al. 2010). Rationality in this connection is seen as the rational, calculated connection between means and ends, as in cost accounting to compute the price of a commodity, for instance, or in finding the quickest route towards a certain geographical point (Clegg and Lounsbury 2009, p. 126). Rationality in this sense is seen as "logical." Such rationality is based on a simplified model of reality as it connects means and ends that are close to one another. Although based on such a simplification, such rationality can be highly complex if one thinks of algorithms optimizing missile flights or logistics operations.

As we will see, there is more to say about rationality than just referring to this calculative approach. We will encounter in this contribution: a lack of rationality, irrationality, organizational hypocrisy, and the distinction between substantive and functional rationality. In this chapter, we will deal with all these manifestations of rationality that occur in all sorts of organizations and certainly also in the military and in what the military does. This will not lead to grand solutions that will solve tenacious problems, but it may spawn insights and understanding of the many dilemmas the military are facing continuously, consciously or subconsciously.

The chapter will start with the build-up of military organizations and its consequences for the military job, followed by analyses of the phenomenon of McSoldiering, the possibility that rationality may turn into its opposite, and the character of strategy- and decision-making in the military. After an exposé on organizational hypocrisy, the chapter will end with an analysis of the problem of collateral damage, which is a damage brought to an area of operations without really being intended. In some way, such collateral damage will be rational, in other ways certainly not. 


\section{Striving for Rationality in the Build-Up of Military Organizations}

Since time immemorial, the formal military organization has been structured according to insights that may be indicated as rational in the sense that the designers have been thinking intentionally about the connections between means and ends. If victory on the battlefield or the occupation of a city, region, or country are the goals to be accomplished, the military organization should be capable to be stronger, faster, smarter, more pervasive, deadlier, and in general more powerful than the adversary. As such, this challenge looks like the design and construction of a building or a machine, as known the work of engineers, the masters of rationality and analysis.

Therefore, military organizations have been structured like an apparatus, in which every part has its functional and unique significance for the performance of the whole device. Roman armies consisted of legions that were subdivided in 10 cohorts, each consisting of 6 centuries that counted about 80 men each. The legion as a whole counted about 5500 soldiers. The first and largest cohort consisted of specialists such as blacksmiths and construction workers. In addition, there were supporting troops, the so-called "auxilia" that were called upon to provide light infantry, logistical and cavalry support (e.g., Goldsworthy 2009). In such an organizational build-up, rationality is associated with machine-like replacement on a dime, of individual soldiers up to divisions, if this would be required in a given situation.

The highly disciplined character of those forces made them successful for centuries. Yet, the highly structured character of the military gradually disappeared in the Middle Ages, until in sixteenth century there were new attempts to make military action explicitly rational again. For instance, the Dutch troops fighting for the independence of their nation were successful against the Spanish Empire because of their highly rationalized ways of operating (Van Doorn 1975). The invention of the musket made it necessary to standardize operational procedures on the battlefield, in a way the opponent was not used to. First, soldiers were no longer allowed to use weapons of their own, as all muskets were provided by the military. Hence, technology became standardized throughout all infantry units. Second, because recharging the muskets took some time, it was essential to train the soldiers to march backwards in a disciplinary manner after they had fired their gun. Arrived at the back of their units, they could start recharging their muskets and gradually move to the frontline again. Through this rational way of organizing, efficient and continuous firepower was certain because once the soldiers had fired and returned to go to the rear end, the next row would take over. The Spanish troops were highly surprised by this way of operating (Soeters 2020, p. 15).

This is a relatively recent example of rational organizing in the military, occurring after the demise of the Roman Empire. But it surely was not the end of this development, it was only the beginning of bringing science into the military (e.g., Bousquet 2009). The nineteenth century witnessed the beginning of the Industrial Revolution. Engineers became increasingly influential as the revolution was based on the invention and introduction of new technologies. Sciences and engineering 
stood at the beginning of their enormous impact in organizations and society (Shenhav 2007), and under this impact, an American practitioner, Frederick Taylor, developed and advocated a way of organizing that became known as scientific management.

He claimed that, like technologies and devices, organizations could be designed making use of scientific knowledge instead of relying on the skills and practices of craftsmen. Presented as scientific methods, Taylor conducted experiments to demonstrate how organizations and jobs could best be organized. His findings led him to formulate principles as to standardization of work methods, the structuring of whole organizations, and the training of skills. No longer should work be done on the basis of the workmanship of smiths, welders, shipbuilders, and construction workers because there was too much variance, ineffective habits and subjectivity in what they had learned during their training on the job (Soeters 2020: $11 \mathrm{ff}$.). From now on, work needed to be done by following precise rules, instructions, and requirements (standards) that were elaborated by work analysts and planners. Planning and doing became separated domains in organizations. In general, Taylorism brings a strong division of labor into the organization, as it favors splitting up the whole of the organizational work into many smaller tasks. Smaller tasks can be executed by people who are specialized in their particular domain of work. Such tasks can easily become routine, in which cases different people can replace each other smoothly, if needed.

Despite resistance by unions and political upheaval about his impact, Taylor became highly influential in the world of business, management, and organizations. The military was also attracted by his insights. The US Navy and Army were highly interested, and through the application of his insights, they were capable of standardizing job instructions and training, hence improving productivity, the quality of maintenance, and even perfecting the use of fire power. Since then, the military organization and the soldiers' job have become Taylorized to a large degree (Soeters 2020: 13 ff.).

Even more than in the times of conscription, today's professional military job is determined by planning, instructions, drills, skills, procedures, standardization, and certification and protocols (King 2013). As an example, today's doctrines and in particular training manuals outline precisely how an ambush can be organized or countered. All this is based on a rational - and in fact acontextual - analysis of means and ends. This way of structuring, training and performing in military work intends to provide:

- More efficiency (doing more with less people and hence less costs)

- More quality (products and services that are ready to use and effective)

- More continuity (easier replacements) and, perhaps most of all

- More safety (preventing injuries and casualties)

Safety to military personnel has become a driving factor in the proliferation of Taylorism in the armed forces, due to the emergence of increasingly impactful weapon systems. After all, working in situations in which one experiences and 
uses violence many things can - inadvertently or not - go wrong, possibly hurting personnel and outsiders. Taylorism has therefore found its place in the military. It surely will remain there, in whatever form or manifestation, even if it is called an organization beyond Taylorism or beyond its practical manifestation, Fordism (King 2006).

Despite the preponderance of Taylorism in the military, there are also rebuttals and suggestions for change, at least to a certain degree.

First, Taylorism brings complexity to the organization. As said, Taylorism favors a strong division of labor. In the military, this could be seen in the Roman army as we saw before, but today it is even more discernible in the various specializations armed forces know today: infantry, logistics-maintenance, logistics-transport, information technology, purchase management, schools and training institutions, different units for specific aircraft or weapons systems, units for civil-military cooperation, engineers, etc. This division of labor has resulted in a "complex organization with simple jobs" as it was once aptly described (De Sitter et al. 1997).

Such an elaborated organizational structure has advantages, because specialization provides more competence and efficiency on the job, but on the other hand, there is a lack of flexibility and control. These disadvantages emerge when specific task forces need to be deployed to missions abroad. Dependent on the character of the mission, the task force needs to be composed according to the task ahead. If the mission is more combat-oriented, infantry units supported by cavalry, artillery, and logistics will dominate the task force. If the mission is more aid-oriented or aiming at civil-military reconstruction, CIMIC-units, health-care elements, and logistics and engineering units will be more important. The process of putting different components before deployment together takes a lot of time, energy, and resources. It is the price one has to pay "for a complex organization with simple jobs." Hence, it may be wise to ponder about different manners of organizing public bureaucracies, such as the military (e.g., Adler 1999). One of such new ways may be modular organizing.

\section{Alternatives in the Build-Up of Military Organizations}

Modular organizing (Schilling and Paparone 2005) emphasizes the build-up of overall organizations consisting of smaller units that can function independently from each other, yet may function together as a whole (De Waard and Kramer 2008). In navies, the principle of modularity is highly developed, as the organization is built around vessels that need to be capable of operating on their own; on navy vessels, everything and everyone needed is on board. Similarly, air forces consist of units that work around the same type of aircraft such as Apaches or F-35's. Every squadron can function on its own because it has all capabilities available including all the supporting workforce to make a fixed number of aircraft operating.

The concept of modular organizing may be helpful for the army too. It may lead to thinking about the design of independent task forces in which all capabilities needed are available. In this, it makes sense if the army would follow basic design principles that are natural to navies and air forces to render deployments easier and 
quicker. The problem, however, is that the army is confronted with such a large gamut of varied tasks dependent on the type of the mission, that it seems hardly feasible to come to a standard type of task force that would fit all purposes. Therefore, the idea of modular organizing, despite its attractiveness, has inflexibilities of its own. The variety of tasks that the army should be ready to do exceeds the number of different task forces that one can organize on a continuous basis. A need to put together elements of different units will therefore always remain.

However, through following ideas of modularity, the degree of such ceaseless combining in armies could be reduced, hence inducing less waste of time and less adaptation problems when a new deployment must be arranged. In such modular task forces, for instance, components dealing with logistics (including the provision of food and health care) will be included in their standard set-up, whereas in the current army, those components need to be "borrowed" from other units when a battalion will be deployed to a mission. This will not solve all problems related to the matching of tasks and organizations, but it will certainly make things easier.

In general, the complexity of the Taylorist military organization, based on the ambition to create as much rationality and efficiency in the individual job as possible, may resonate in longer "production and delivery times," so to speak. For instance, the purchase of goods is a complex matter in defense organizations, leading sometimes to inadequate or not timely delivered supplies of goods, such as boots, helmets, computers, or even vehicles in the area of operations. The reason is that there are many steps in this process that are taken by different specialists in the organization: identifying the need for certain goods by commanders, acquiring the required resources via specific procedures by purchasing specialists, receiving the goods and getting them on the proper place by logistic personnel, and paying the bills by financial people. Because the process is so elaborated and because so many different personnel are involved - all because it is "rational" to do so - this is a timeconsuming and sometimes even annoying process.

This process may become seriously maddening when people on the various spots in the organization hinder each other when they place too much weight on their own rules, interests, and practices. This may occur if personnel - due to the organizational context in which they are employed - focus too much on their own job, because "where you sit is where you stand." In such situations, one is not really bothered about the larger picture to which their actions contribute. In such cases, the process simply requires too much time, possibly leading to operational personnel not having adequate supplies and equipment in the field, as said before. It is the price one has to pay for rationalization and efficiency-improvements in smaller parts without regarding the rationality in the whole of the organization. Of course, the process of purchasing goods is only one example. The military organization knows endless numbers of such examples.

Reviewing the process of structuring armed forces, one can state that rationality in its calculative, "logical" sense - based on planning and analysis to make the best of means to reach ends - has played a role that can hardly be overestimated. Yet, with an emphasis on one aspect of organizational processes, a lack of attention to other aspects of work configurations may occur This may become manifest in delays, a 
lack of cooperation, unconcern about the total picture of what the organization does, and indifference towards the workers and customers (e.g., Adler 1999). This may have adverse effects. We will be seeing more of this in the remainder of the chapter.

\section{McSoldiering in the Armed Forces?}

The American sociologist George Ritzer (1993) analyzed the growing dominance of rationality in organizations, for which he took the work procedures of the Hamburger chain McDonalds as the prime example. This fast-food chain stresses that the preserving, cooking, and preparing of their foods are done always and everywhere in exactly the same manner. Personnel in the McDonalds stores all over the world use the same ingredients, the same equipment, the same temperature, the same cooking time, and the same expressions while delivering the orders. A hamburger purchased at one of this chain's stores is identical in Shanghai, New York, Amsterdam, Cape Town, and in all other places on the planet. Standardization is the magic word here; this ensures that workers and customers always know what to expect and that no time, costs, or products are wasted. It is scientific management at its best.

Following up on this, Ritzer coined the phrase "McDonaldization of society." With this term, he wanted to analyze how such organizational processes - striving for efficiency, calculability, predictability (via standardization), and full control - are capable of dominating increasing domains of work and life. These domains not only include business, finance, and food production but also health care, education, and the media. Even medical doctors and nurses need to work according to standards and protocols that have been formulated at some central point. Not complying with these rules, standards and instructions will make the workers lose their professional qualifications, their "licence to operate." The logic behind this is that not complying with the rules and standards may be detrimental to the patients' and the workers' own health and safety, as well as to the general efficiency and costs in the health system. Striving for efficiency fits perfectly well with the current, larger economic system based on market competition that dominates in most countries in the world, albeit with variations.

Military sociologist Morten Ender (2009, pp. 67-86) pursued this line of thinking and raised the question if today's professional soldiers are McSoldiers, in other words "human tools" such as in the hamburger chain, or the opposite, innovative professionals. His work was based on findings on US soldiers deployed to Iraq. He found that there was no clear answer to this question. The soldiers in Iraq of course followed and used all skills, drills, and tactics they had learned in training and exercising at home (e.g., King 2013). This of course leads to predictability and control in operations all over the world, which are positive essentials of rational organizing. Also, junior commanders did not receive a lot of space to make decisions on their own; this again increases predictability and the use of standard operating procedures, which is important to avoid military action getting out of control. On the other hand, such constraints while in action impede flexibility and creativity on the spot. It has been stated before that junior officers, company commanders in 
particular, are too rarely given the opportunity to be innovative and make decisions on their own (e.g., Wong 2002, p. 3).

This is not to say the soldiers and their (junior) commanders are not innovative at all. In Iraq, when the rank-and-file and junior commanders were confronted with problems related to maintenance, such as broken equipment and vehicles, the soldiers were apt at making repairs and improving safety conditions. Among others, they were keen on "up-arming" their vehicles as the standard vehicles were not safe enough to protect against IEDs. As such, the soldiers on the ground were certainly also adaptable, creative, and innovative personnel. All in all, the US soldiers in Iraq were both "human tools" and innovative professionals, according to Ender (2009). This will not be any different for military men and women from other countries who have experienced the heat of operating in missions such as in Iraq and Afghanistan.

It remains to be seen, however, if soldierly creativity and innovativeness remain limited to maintenance and repairs at the base or also translates to situations that are more operational, such as in contacts with host-nationals on the streets. After all, soldiers in today's missions are thrown into situations that can quickly change from hostile, combative engaging to calm interacting with ordinary people who all have their own traditions, beliefs, sentiments, habits, and memories. At the end of the day, creativity and innovativeness during action is likely to have a larger impact on smoothing hostile tensions than being handy at repairing equipment. Given the wide range of different types of operations, stressing McSoldiering - i.e., continuous displaying standard, oftentimes conventional kinetic, repertoires of action (e.g., King 2013) - may not always be the best option to solve the tensions and hostilities in a conflictual region. Yet, it proves hard to divert this McSoldiering aspect of today's armed forces. Traditional combat training and its consequential lust for hard warfighting are simply too strong to be altered easily (e.g., Catignani 2014). This seems to be true despite pleas, arguments and attempts to change the content of military education (e.g., Sookermany 2017) and despite endeavors to introduce exercises that relate to population-centric approaches instead of enemy-centric approaches (e.g., Catignani 2014). Apparently, there is a sort of dynamic conservatism in military organizations, which implies that proactive changes only seem to result in remaining the same (Ansell et al. 2015).

\section{The Irrationality of Rationality}

One of the consequences of McDonaldization, says Ritzer (1993), is that rationality may turn into its opposite; this is what he calls, the "irrationality of rationality." According to Ritzer (1993, p. 121), rational systems at some point in time inevitably produce inefficiency, unpredictability, incalculability, and loss of control. Even more striking is that rational systems at the end of the day may become unreasonable systems; indifference towards human aspects, i.e., dehumanization, may become an ultimate consequence of such a process. This is more likely to occur if one type of interests is stressed at the expense of the interests of others. 
For instance, the interests of the producer and purveyor of services may dominate the interests of the customer (Ritzer 1993, p. 123). Or the benefits of the employers may overshadow the interests of the employees, those of the commanders the interests of the soldiers and sailors, or those of the deployed militaries the welfares of the host-nationals. Higher status occupations and situations in which one has more power in general provide more opportunities to create non-rationalized niches, says Ritzer (1993, p. 179). The rule seems to be that those with power tend to impose organizational rationality - standardization, efficiency, predictability - on others, while keeping one's own work as nonrational, i.e., as not-standardized and notcontrolled, as possible. Organizational rationality, hence, seems to have a vertical dimension: more at the bottom, less at the top.

In his work on McSoldiers among US military personnel deployed to Iraq, Ender (2009, pp. 81-82) observed many examples of such irrationality of rationalities. The soldiers in his study complained about unreasonable tasking such as having too little personnel to do the jobs, failing maintenance, reckless assignments, and unreasonable leaders. Such irrationality occurred both on and off the base. Here, the conflict of interests turning rationality into irrationality was based on the divergence of interests between politicians and military personnel, and between commanders and soldiers. Ender's findings specifically relate to what the soldiers, the workers on the ground, feel to be unreasonable with respect to their own work conditions. We will later see how such a conflict of interests - the way Ritzer talked about it - may also refer to the differences in the military's and host-nationals' working, living, and safety conditions and actions.

\section{Limits to Rationality in Decision-Making}

Another aspect of irrationality, or better perhaps: lack of rationality, in (military) organizations refers to the formulation of strategies, and more in particular decisionmaking. In a small but illuminative book based on earlier work, James March (1994) explained how decisions happen. One of the most striking parts of the book refers to what he and two co-authors labelled "garbage-can-decision-making."

In general, March did his utmost best to make clear that decision-making is far less rational than many people are inclined to think. Rational decision-making presupposes that decision-makers have full information and calculation capabilities: in this assumption, decision-makers know everything there is to know, including their own preferences, and they can fully assess the relative weight of each variable in the outcome of a decision-making process. Both ideas are wrong.

Decision-makers usually don't have all the information they need nor are they able to calculate all possible options. That is because they experience the impact of small groups dynamics and more importantly, because they have cognitive limitations and biases, such as an illusion of control and an optimistic bias, related to an insensitivity to prior knowledge and statistical notions. Those are limitations and biases decision-makers share with all human beings (Kahneman 2011). What is more: human beings usually don't strive to obtain maximum results because cultural 
rules and institutional conditions such as laws, contracts, policies, habits, and practices prevent this from happening, as these create boundaries and limits to what may be achieved. For sure, decision-making definitively is a matter of bounded rationality.

Having this in mind, March analyzed how decision-making gets complicated when many things happen at the same time and change and interact continuously. Therefore, it is often difficult to connect problems with preferences, preferences with decisions, and decisions with outcomes. All this is a manifestation of ambiguous decision-making or even "garbage-can-decision-making," as it has been coined so creatively. In such situations, decision-making can be seen as "collections of choices looking for problems, issues and feelings looking for decision situations in which they might be aired, solutions looking for issues to which they might be an answer, and decision makers looking for work" (Cohen et al. 1972, p. 1). In such situations, chaos reigns over rationality because choices and decisions are hardly connected to the problems at hand.

Some may say this perhaps occurs in universities or politics, but not in the military, let alone in military operations. Those people are mistaken. March himself co-edited a volume on military decision-making. In this volume, Weissinger-Baylon (1986) pointed at the fact there are many ambiguities in decision-making that are specific to the military and warfare. Ambiguities in the military relate to technologies as well as to preferences and participation of politicians. In general, military personnel, even among the highest ranks, don't precisely know what technologies may provoke once being put into action, nor are they fully aware of what politicians in fact want and value. At the same time, during operations, there is considerable decision "load." The way to cope with such ambiguities is standardization, operational plans, and centralized decision-making.

Yet, this will not solve the essence of the problems. In operations in particular, "solutions are looking for problems," which happens when military officers don't rest until they can make use of their specific skills or capabilities and do the job they have been trained for. This could, for instance, be the use of air power as preferred by fighter-pilots or engagements in ground combat fancied by Marines (Hugues 1986, p. 255). This tendency may be rational based on the professional training these soldiers have undertaken prior to their execution. Still such use of force may turn out to be irrational if it, in fact, would create adverse results in the whole of the operations. There are many examples of dynamics making things worse instead of better, the Vietnam War being only one of those.

The above primarily refers to decision-making in military action. More general policy-making about military organizations and their missions shows even more specific characteristics.

\section{Organizational Hypocrisy in Military Policies and Operations}

Nils Brunsson, a Swedish management scholar, introduced the idea of organizational hypocrisy in policy and organizational decision-making. He did so, emphasizing that organizations, and the people in them, in principle are irrational 
(Brunsson 1985; Soeters 2020, pp. 215-227). This, of course, was a stone in a calm pond, because in organizations, rationality, if not accomplished, should at least be strived for. However, Brunsson's thinking was not pessimistic, let alone depressive. He stated that for organizations to survive, they simply have to behave irrationally, at least to some degree, sometimes or most of the times.

In line with the analyses provided by James March (1994), Brunsson argues that pure rationality in decision-making is not possible: people are biased and limited in their cognitive capabilities and they adhere to organizational ideologies, or valuesystems. Organizational ideologies - sets of cultural rules, so to speak - solve a large part of the decision problem. They focus the employees and other possible stakeholders on just a few aspects of reality, and the employees are committed to the organization's action through these ideologies. As a consequence, members' confidence in their biased perceptions exceeds what seems justified from a rational perspective (Brunsson 1982, p. 42).

Pursuing these ideas, Brunsson (1993) authored a highly interesting analysis of what he framed as organizational hypocrisy. He starts again with the observation that organizations are only rarely fully rational. Furthermore, he makes a distinction between decisions and actions, between saying and doing. Oftentimes, he argues, saying and doing are not consistent, put differently, decisions and actions are decoupled. There are two ways in which this occurs.

The first inconsistency - saying something and not doing it - relates to desires, wishes, ambitions, and normative statements that express different values without being a real endeavor to achieve something (Brunsson 1993, p. 491). Such desires and demands may be unrealistic because of a lack of knowledge or simply because one does not have the time or resources to turn them into reality. After all, the most attractive ideas and ambitions may not be the most feasible. The second inconsistency - doing something that cannot be said - is connected to ethics, aesthetics, and truth. In Brunsson's (1993, p. 492) own words: "ethical norms tend to limit what we can say, more than what we can do." People often do things they find difficult to acknowledge and defend in the open. An example is the export of arms. Many nations disapprove of this whereas they make it happen anyway because it helps foster the national economy.

There are two mechanisms to make both inconsistencies work. The first one is justification, which is defending or making acceptable of what is being done, or not. Actions should be made obvious and presented as making sense, by stating "there is no alternative" (TINA). Budget cuts on public facilities are often made "obvious," because the "national economic situation does not allow to act differently." This is said while "forgetting" or deliberately not pointing at other options to economize or to gain more income, for instance, via the taxation of private capital gains. The other way is organizational hypocrisy, which occurs if it is difficult to justify actions; in such situations, the talk is in the opposite direction of what is being done (Brunsson 1993, p. 501). Then, the official truths deviate from everyday practices.

All of this can be recognized in the domain of military and security affairs. The US government's demand that NATO allies substantially increase their defense budget is certainly connected with their own national weapon industries that can 
use every bit of foreign purchases (Dunlap 2011). The justification, however, is that the security situation in Europe, particularly due to Russia's behavior, urges the European allies to strengthen their military capabilities. Organizational hypocrisy, on the other hand, emerges in the same area, when European allies such as Germany, Spain, Belgium, and the Netherlands say they are going to spend $2 \%$ of their national income to defense, while they remain far from doing that.

Organizational hypocrisy in higher politics relates to organizational hypocrisy with respect to operations. The Italian scholar Eugenio Cusumano (2019) applied the idea of organizational hypocrisy to the border control practices of the EU vis-à-vis irregular migration across the Mediterranean Sea, offshore Libya. These practices contained a structural inconsistency, starting with their emphasis on the conduct of maritime search and rescues (SAR) operations that intend to help refugees in need on the sea. The use of the words "rescue" and "save" was dominant in the mission's communication with the outside world. In reality, Cusumano (2019) showed, the operations were only limitedly focused on search and rescue, prioritizing border control, the curbing of irregular immigration and anti-smuggling tasks instead. According to Cusumano, there was a clear decoupling of talk and action, hence making this a clear example of organizational hypocrisy. Even though this is to some degree understandable due to the conflicting external demands, such organizational hypocrisy may be detrimental to the credibility of the acting organizations and the objectivity of the assessment of the operations. Besides, moral hazards and dilemmas may arise among the mission's personnel.

Before Cusumano, the Canadian scholar Michael Lipson (2007a, b) had applied the ideas of "garbage-can" decision-making and organizational hypocrisy to one of the military's central activities, UN peace missions. He analyzed the process of decision-making and started with the observation that the UN structurally struggles with conflicting pressures, demands, and views. There are many stakeholders who all have their own views, ideologies, and interests. The UN has to support goals that now and then may turn out to be contradictory, such as defending human rights and recognizing nations' sovereignty. As a consequence, the UN produces talk and decisions more than it solves problems through action (Lipson 2007a, pp. 12-13).

There are serious problems of this type in the context of the UN, one of them being the commitment gap. This gap evolves because major military powers such as the USA and the UK are very much in favor of protecting human rights but refuse to participate in peace missions in a way that is commensurate to their military capabilities. They prefer to be involved in allied combat-type missions such as in Iraq and Afghanistan. The same applies to Russia that despite some assistance in peace missions prefers to engage primarily with air operations or secret, hidden yet coercive operations of their own. The contribution of well-funded European militaries has been limited too, at least compared to the contribution by developing countries, such as India, Pakistan, Nepal, Senegal, and Nigeria. Saying one thing while doing the other is what characterizes a lot of major countries' international behavior. Such organizational hypocrisy in the UN also occurs when the problems run out of hand and the use of force seems to be the only solution to the problem that one faces. In such cases, the UN delegates the job of using force to other actors such 
as NATO, which happened, for instance, after the failure of the UNPROFOR mission in Srebrenica, Bosnia, in July 1995. This too can be seen as a specimen of organizational hypocrisy (Soeters 2020, p. 223).

All this is not to say that UN peacekeeping is bad per se, or should be ended. On the contrary, peacekeeping contributes a lot to maintaining peace, albeit with limitations, in many places in the world. Organizational hypocrisy and the corresponding limitations in rationality is inevitable to make things work, as Nils Brunsson would say. The world would be worse off without it, no matter how paradoxical this may seem.

\section{Collateral Damage, Functional and Substantive Rationality}

A final point to discuss when reviewing rationality and irrationality in the armed forces refers to the ever-present issue of collateral damage resulting from military action. Collateral damage is loss and destruction resulting from military action that was not intended but taken for granted. If something is taken for granted, it is clear to everyone involved what is appropriate and what is not, and what can be ignored anyway. Underlying ideas are not scrutinized because they are "self-evident" and provide a sort of "mental tunnel"; these ideas differ from one group - or "thought community" - to another (Zerubavel 1997: 35 ff.). In military communities, consequences of combat are often taken for granted, which means they can simply be ignored.

The Polish sociologist Bauman (2011) analyzed this phenomenon, starting with a truism that is popular among military men and women: "you can't make an omelette without breaking eggs." Bauman's subsequent words are too valuable not to be quoted: "What is glossed over in such a case is, of course, someone's legitimized or usurped power to decide which omelette is to be fried and savoured and which are the eggs to be broken, as well as the fact that it won't be the broken eggs who savour the omelette..." (Bauman 2011, p. 5). And he continues with: "Thinking in terms of collateral damage tacitly assumes a priori an already existing inequality of rights and chances (...)" (Bauman 2011, p. 5). When hungry, making an omelette seems a rational thing to do, but looking at this from more than one angle, limits to rationality emerge, once again.

A relatively recent example of collateral damage refers to an airstrike by Netherlands' F-16's in 2015 on a factory and warehouse of explosives in Hawija in Iraq, killing about 70 people and destructing or damaging some 400 buildings in the direct surroundings (NOS 2020). The damage was caused in particular by secondary explosions that resulted from the bombing. Even though pre-mission analyses had indicated the plan to bomb that specific target as particularly hazardous, the Netherlands' commander supported by a legal specialist approved the strike. This is only one example of many incidents bringing about collateral damage occurring since the beginning of the missions in Iraq and Afghanistan, and later in Syria where armed forces on all sides of the spectrum were responsible for loss and destruction that "simply comes along with military action." 
There is a major phenomenon that enables such thinking and justifying, and it is related to the build-up of organizations in general, and military organizations in particular. As we saw before, organizations know a strong degree of work division and a corresponding specialization in the jobs because they strive for as much rationality as possible. In air forces this implies that the meteorologist makes sure her weather forecasts are correct, the maintenance mechanics ensure the aircraft is ready to fly safely, planners and other specialists identify the targets and assess exante how much damage will occur, and the pilots at the end of the chain conduct the airstrike. All these tasks are conducted in a highly protocolled manner and everyone is interested in doing his or her own job excellently. However, no one questions the broader implications of what is being done. Rarely anyone is interested in seeing the bigger picture.

People involved are interested whether or not the target was destroyed properly (preferably without a lot of collateral damage) and the pilots returned to home base safely. That is rationality, for sure; it is direct-means-ends-rationality, the way we saw before. In sociology, this is known as "ends rationality" or functional rationality. Yet, almost nobody ponders the general impact of such bombing in relation to the dynamics of the hostilities in the region nor in relation to moral or ethical considerations vis-à-vis the host-national people. Did the destruction of that target contribute to ending the adversaries and bringing about peace in the area of operations? Such questions are hard to raise as it would create doubts as to what is being done during the operations in a certain area and conflict. Personnel could risk their career perspectives raising such rebuttals. However, this is also rationality, but one of a broader nature; this is rationality that sociologists refer to as "value rationality" or substantive rationality (Clegg and Lounsbury 2009; Soeters 2018, 2020). Clearly, what may be rational from one point of view, may be different, or less so, from another perspective (e.g., Alveson and Spicer 2016).

If public outrage emerges because something seriously went wrong, such as sometimes happens in relation to military operations and their consequences, organizations tend to use a gamut of tactics to forget this act of "corporate irresponsibility" (Mena et al. 2016). The first tactic, of course, is to broadcast a strategic narrative that emphasizes the ideas that military action equals combat and war, and that combat and war come along with a price one simply has to pay. This is the omelette-metaphor we saw before. If this narrative, this tunnel-reasoning, is accepted by the wider population, no "forgetting work" is needed.

In other situations, the organization needs to employ tactics to manipulate stakeholder perceptions, both inside and outside the organization, such as those of journalists and members of parliament. This may happen by diverting attention away from the event, downplaying its harmfulness and distorting the attribution of the blame. If things get worse, tactics are used to silence people who try to raise questions (by ousting, ostracizing and firing them, besmirching their reputation in informal gossip and talks, or simply never have them involved, for instance, by stopping invitations to participate). These tactics are particularly effective if those others act less coordinated, i.e., not strengthening and supporting each other, and if they are unable to express their claims meaningfully. Finally, tactics of "forgetting work" aim at undermining by fabricating alternative stories and explanations, and 
sometimes even destroying evidence (documents, physical objects). Sometimes, there is mention of "structural amnesia."

Of course, such "forgetting work" occurs in civilian affairs, but surely it has been, is, and will be applied to many events that happened, happen, and will happen in military operations. Examples are the notorious Pentagon Papers referring to the Vietnam War (Soeters 2020, pp. 69-70), the Afghanistan Papers that recently came into the open (Whitlock 2019), and the way two subsequent Ministers of Defence in the Netherlands tried to avoid debate in national parliament about the Hawija bombing that was discussed above. In Russia, the "forgetting work" with respect to the demise of a submarine, the Kursk, is another notorious example (Barany 2004). Such "forgetting work" does not help to foster the degree of substantive rationality in the military.

\section{Summary}

This chapter aimed to produce insights with respect to rationality and irrationality in the military, as well as the various forms in between these two extremes. This contribution does not intend to complicate matters but to make military people aware they are not so rational as they possibly think they are. Rationality is human business and, henceforth, it is surrounded by dilemma's, emotions, habits, divergences in views, and cognitive limitations and biases. What is more, military people "cannot even conceive of a technological object (=military action/JS) without taking into account the mass of human beings with all their passions and politics and pitiful calculations (...)" (Latour 1996: viii). Military personnel need to face the dilemma of combining a broader awareness with the time-pressured technicalities of performing their relatively small operational tasks.

\section{Cross-References}

- Behaviour Economics

- Challenges in HRM in Military Organizations

$\checkmark$ Defence Management and Economics

- Dynamic Intersection of Military and Society

- Hybrid Organizing

- Management, Economics and Logistics in Military Sciences

- Military Behaviour and Ethics

- Military Design

- Military Psychology

- Military Sociology

- Rationality and Irrationality in Military Organizing

$\checkmark$ Strategy and Doctrine

- The Role of Operational Research in Military Personnel Management 


\section{References}

Adler, P. S. (1999). Building better bureaucracies. Academy of Management Executive, 13(4), 36-47.

Alveson, M., \& Spicer, A. (2016). The stupidity paradox. In The power and pitfalls of functional stupidity at work. London: Profile Books.

Ansell, C., Boin, A., \& Farjoun, M. (2015). Dynamic conservatism: How institutions change to remain the same. Research in the Sociology of Organizations, 44, 89-119.

Barany, Z. (2004). The tragedy of the Kursk: Crisis management in Putin's Russia. Government and Opposition, 39(3), 476-503.

Bauman, Z. (2011). Collateral damage. Social inequalities in a global age. Cambridge: Polity Press.

Brunsson, N. (1982) The irrationality of action and action rationality: decisions, ideologies and organizational actions. Journal of Management Studies 19(1), 29-44.

Brunsson, N. (1985). The irrational organization. Irrationality as a basis for organizational change and action. Chichester/New York: Wiley.

Brunsson, N. (1993). Ideas and actions: Justification and hypocrisy as alternatives to control. Accounting, Organizations and Society, 18(6), 489-506.

Catignani, S. (2014). Coping with knowledge: Organizational learning in the British army? Journal of Strategic Studies, 37(1), 30-64.

Clegg, S., \& Lounsbury, M. (2009). Weber: Sintering the Iron Cage. Translation, domination and rationality. In P. Adler (Ed.), The Oxford handbook of sociology and organization studies (pp. 118-145). Oxford/New York: Oxford University Press.

Cohen, M. D., March, J. G., \& Olsen, J. P. (1972). A garbage can model of organizational choice. Administrative Science Quarterly, 17(1), 1-25.

Cusumano, E. (2019). Migrant rescue as organized hypocrisy: EU maritime missions offshore Libya between humanitarianism and border control. Cooperation and Conflict, 54(1), 3-24.

De Sitter, L. U., den Hertog, J. F., \& Dankbaar, B. (1997). From complex organizations with simple jobs to simple organizations with complex jobs. Human Relations, 50(5), 497-534.

De Waard, E., \& Kramer, E. H. (2008). Tailored task forces: Temporary organizations and modularity. International Journal of Project Management, 26(5), 537-546.

Dunlap, C. (2011). The military-industrial complex. Daedalus, 140(3), 135-147.

Ender, M. (2009). American Soldiers in Iraq: McSoldiers or innovative professionals? London/ New York: Routledge.

Goldsworthy, A. K. (2009). The Roman Army at war 100 BC-AD 200. Oxford: Clarendon Press.

Hugues, W. P. (1986). Garbage cans at sea. In J. G. March \& R. Weissinger-Baylon (Eds.), Ambiguity and command. Organizational perspectives on military decision making (pp. 249-257). Marshfield: Pitman.

Kahneman, D. (2011). Thinking, fast and slow. London: Allen Lane.

King, A. (2006). The post-Fordist military. Journal of Military and Political Sociology, 34(2), 359-374.

King, A. (2013). The combat soldier: Infantry tactics and cohesion in the twentieth and twentiethfirst centuries. Oxford: Oxford University Press.

Latour, B. (1996). ARAMIS of the love of technology. Cambridge/London: Harvard University Press.

Lipson, M. (2007a). Peacekeeping: Organized hypocrisy? European Journal of International Relations, 13(1), 5-34.

Lipson, M. (2007b). A 'garbage can model' of UN peacekeeping. Global Governance. A Review of Multilateralism and International Organizations, 5(3), 79-97.

Mena, S., Rintamäki, J., Fleming, P., \& Spicer, A. (2016). On the forgetting of corporate irresponsibility. Academy of Management Review, 42(4), 720-738.

NOS. (2020). Amerikanen waarschuwden voor burgerdoden bij Nederlands bombardement Hawija. [translation: Americans warned there would be civilian casualties as a result of the Dutch bombing of Hawija] April 21. https://nos.nl/2331199 
Ritzer, G. (1993). The McDonaldization of society. An investigation into the changing character of contemporary life. Thousand Oaks: Pine Forge Press.

Schilling, M., \& Paparone, C. (2005). Modularity: An application of general systems theory to military force development. Defence Acquisition Review Journal, 279-293.

Soeters, J., van Fenema, P. C., \& Beeres, R. (Eds.). (2010). Managing military organizations. Theory and practice. London/New York: Routledge.

Sookermany, A. M. (2017). Military education: A postmodern update. Journal of Philosophy of Education, 51(1), 310-330.

Van Doorn, J. A. A. (1975). The soldier and the state: Comparative studies in the history and sociology of the military. Beverly Hills/London: SAGE.

Weissinger-Baylon, R. (1986). Garbage can decision processes in Naval warfare. In J. G. March \& R. Weissinger-Baylon (Eds.), Ambiguity and command. Organizational perspectives on military decision making (pp. 36-52). Marshfield: Pitman.

Whitlock, C. (2019). At war with the truth. The Afghanistan Papers. Washington Post, December 9. $\mathrm{https}$ //www.washingtonpost/graphics/2019/investigations/afganistan-papers/afghanistan-warconfidential-documents

Wong, L. (2002). Stifled innovation? Developing tomorrow's leaders today. Carlisle: Strategic Studies Institute.

Zerubavel, E. (1997). Social mindscapes. An invitation to cognitive sociology. Cambridge, MA/ London: Harvard University Press.

\section{Further Reading}

Bousquet, A. (2009). The scientific way of warfare: Order and chaos on the battlefields of modernity. London: Hurst \& Company.

March, J. G. (1994). A primer on decision making. How decisions happen. New York: The Free Press.

Shenhav, Y. (2007). Manufacturing rationality. The engineering foundations of the managerial revolution. Oxford/New York: Oxford University Press.

Soeters, J. (2018). Sociology and military studies. Classical and current foundations. London/New York: Routledge.

Soeters, J. (2020). Management and military studies. Classical and current foundations. London/ New York: Routledge.

Open Access This chapter is licensed under the terms of the Creative Commons Attribution 4.0 International License (http://creativecommons.org/licenses/by/4.0/), which permits use, sharing, adaptation, distribution and reproduction in any medium or format, as long as you give appropriate credit to the original author(s) and the source, provide a link to the Creative Commons license and indicate if changes were made.

The images or other third party material in this chapter are included in the chapter's Creative Commons license, unless indicated otherwise in a credit line to the material. If material is not included in the chapter's Creative Commons license and your intended use is not permitted by statutory regulation or exceeds the permitted use, you will need to obtain permission directly from the copyright holder.

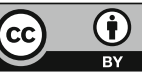

